\title{
NAMES AND IDENTITIES \\ IN THE ITALIAN DETECTIVE STORY
}

\author{
MARIA GIOVANNA ARCAMONE \\ University of Pisa
}

\section{A B S T R ACT}

Detective stories were established in Italy at the end of the nineteenth century in imitation of the 'noir' and the French and English serial novels. The Italian detective story over time has grown also with some of our better writers and it is to stories written by Carlo Emilio Gadda, Leonardo Sciascia, Carlo Fruttero/Franco Lucentini, Carlo Fruttero and Andrea Vitali that this paper is dedicated to investigating. In addition, all these authors reveal with linguistic reflections that they appreciate the inherent power of Proper Names. The detective novel is especially appropriate on the relation between proper names and identity. Indeed, normally at the beginning of events both in the real world and in detective fiction the personalities present in the good and bad texture of events have not yet been identified. These authors of Italian detective stories look for an ally in the nominatio to help them define the identity of their characters and the backdrop of their story.

\section{[1] INTRODUCTION}

In Italy the detective story is also called a 'giallo' (yellow). This name derives from the colour of the book cover of a series of detective stories which the publisher Mondadori inaugurated in 1929 calling them 'yellow books' (gialli) (Crovi 2002). One can say that detective stories were established in Italy at the end of the nineteenth century in imitation of the 'noir' and the French and English serial novels (above all those regarding the mysteries of Great Cities), but soon they began to take on their own characteristics, especially given the great number of trials that shocked Italian society at the turn of the twentieth century.

Scholars who have examined Italian detective stories in their complexity have given the following global judgement upon them: first and foremost blood, love and money must never be lacking; further, often a sleepy provincial town is preferable to the mysteries of big cities; the rich bourgeoisie should feature, as should some typical forces of law and order; and finally special emphasis should be given to the psychological aspects of the investigation (Reuter 1997; Crovi 2002).

The detective story over time has become a mask symbolizing the tragic nature of our era. Furthermore it has grown also with some of our better writers and it is to some stories written by Carlo Emilio Gadda, Leonardo Sciascia, Carlo 
Fruttero together with Franco Lucentini, Carlo Fruttero and Andrea Vitali that this paper is dedicated to investigating. In addition, all these authors reveal with linguistic reflections that they appreciate the inherent power of proper names. I hold that the detective novel is especially appropriate, for today's discussion, on the relation between proper names and identity. Indeed, normally at the beginning of events both in the real world and in detective fiction the personalities of everyone present in the good and bad texture of events are not yet identified.

In real life the identity of a person is consolidated. In general it is enough to check the name and surname, national insurance number, address and little else such as stature or eye colour. Today we have digital finger prints. The identity of a person means being this person and not someone else. It is obtained via a complexity of characteristic and fundamental data that allow individuality or guarantee authenticity, especially regarding birth registration and other bureaucracy. The first data in order of importance, both in real life and in stories, are birth registration data. This is unavoidable; hence we have given name and surname.

In a literary work, and in fiction in general, the identity of someone or something necessitates a more complex operation since everything has been created from scratch and because the character is not present in his/her physicality. His/her identity emerges bit by bit through descriptions of behaviour, habits, reflections on his/her personality and traits, etc.; and also, for the reasons given above, with the attribution of a name or surname or name and surname, sometimes even a nickname, in a direct or indirect manner.

In fiction, though, however much data needs to be amassed, identification the construction of the personality of a character - is a much more laborious task than in real life; for everything is missing and so every element must be very well chosen and evaluated. This implies that also proper names become carriers of more than one piece of information. This is obtained by choosing 'telling names' and allusive names and delaying the character's appearance or having them introduced by others, etc. (Debus 2002; Porcelli \& Terrusi 2005).

What this amounts to is a requirement that proper names in fiction should be strong carriers of clues (to the character's personality) and in detective stories (conforming to the structure of the genre already mentioned) they should be so to a higher degree compared with other literary genres, since it is precisely clues that detective stories are based on.

In Italy, many studies are being carried out on detective stories and their authors. However, it is only in the last couple of years that onomastic study in this literary genre has started to be conducted (Sciascia 1983; Porcelli \& Terrusi 2005; Arcamone 2007; Porcelli 2009). I have therefore investigated the functions of proper names (PNs) in a few Italian detective novels. These novels are: Quer Pasticciaccio brutto de via Merulana (That Ugly Mess in Via Merulana) by Carlo Emilio 
Gadda (Gadda 1957), Il giorno della civetta (The Day of the Owl) by Leonardo Sciascia (Sciascia 1961), La donna della domenica (The Sunday Woman) by Carlo Fruttero and Franco Lucentini (Fruttero \& Lucentini 1972), La modista (The Milliner) by Andrea Vitali (Vitali 2005), and Donne informate sui fatti (Women Informed of the Facts) by Carlo Fruttero (Fruttero 2006). As I said earlier I have preferred to choose authors who are not dedicated exclusively to the 'whodunnit' genre but who are also actively productive in other literary genres. So much so that these authors show that they are aware of the strength inherent in proper names, as is revealed by their own linguistic reflections. It is not without significance that all these stories, apart from the most recent ones just published, have been made into movies or theatre, thus demonstrating their strong realism. To begin with, I shall introduce the contents and some of the characters of the texts to be examined and evaluate them chronologically.

\section{[2] QUER PASTICCIACCIO BRUTTO DE VIA MERULANA}

Quer pasticciaccio brutto de via Merulana (That Ugly Mess in Via Merulana) by Carlo Emilio Gadda, was officially published in 1957, though it had appeared in serial form as early as 1947. It is set in Rome during the years the author himself was in Rome - in the Fascist era. The story is about a woman from a good family living in Rome under Fascism. Her given name is Liliana, her maiden name Valdarena. She is brutally murdered in her own house. The police inspector, Dottor Francesco Ingravallo, follows many trails around Rome and its well-known surrounding towns near the Castelli Romani and the Alban Hills. There are many suspects, but no murderer is ever found and the novel ends unresolved, like many other investigations in real life in Italy.

The main characters' identities, constructed by means of brief, pithy descriptions (Gioanola 2004), are reinforced by their names, surnames and nicknames, and are seen primarily as 'speaking names' or as allusive names on the basis of their appearance within the work (Amigoni 2002; Terzoli 2007). For example, the police inspector is introduced immediately at the beginning of the novel. First we learn of his nickname, Don Ciccio, then immediately his name and surname: 'Anyway everybody calls him Don Ciccio. He was Inspector Francesco Ingravallo Mobile Commander.' Ciccio is a southern Italian hypocorism for Francesco, which, by contrast, is pan-Italian (De Felice 1986, 175). Ciccio, being a southern Italian hypocorism (Rossebastiano \& Papa 2005, 270) together with Don (< Lat. Dominus) and together with the surname Ingravallo - typically of the Region of Molise in Italy (Minervini 2008, 28, 31) - immediately indicates that the character is of Southern Italian origin, as policemen generally are in Italy, and as they are in other novels. His authoritative ways of doing things, the fact he's a Don, and the morpheme grav - encapsulated in the surname Ingravallo, all allude to the gravity and seriousness with which he approaches his work. However, he is also down to 
earth. 'Everybody calls him Don Ciccio.', i.e. by his nickname which is also an allusive name because It. ciccio means plumpish (Devoto \& Oli 1990, 375). The reader almost inevitably thinks of the colloquialism ciccione (plump) and in fact a little later is described as being 'of medium stature, a rather rotund person, or maybe a little stocky...he had a rather sleepy air about him, a heavy gait, a dull-witted approach!' Here the grav- (serious, important) is reaffirmed in his surname Ingravallo. It was during the First World War that the migration to Rome of Italians from Abruzzo and Molise increased, as the presence of many Abruzzo trattorias in Rome testifies. And it is today's Roman cuisine that has been influenced by recipes from Abruzzo. It is in fact expressively stated that he comes from Monte Matese, which is in Molise. This insistence on good cuisine often returns and reaffirms that the character originates from Molise. In fact he loves good food and a good glass of wine and every now and again he has the odd stain of olive oil on his collar which is almost imperceptible; it is however 'almost a reminder of the hills in Molise'. Also various surnames such as Crocchiapani (munch bread), Bottafavi (squash broad beans) refer to food.

He is reflective, lazy and half asleep. He is, however, gifted with a flawless memory. He is often invited to lunch by his good friends, the Balducci family. The lady of the house, Signora Liliana, is beautiful and very rich, more so than her husband. She is still young but very sad because she can't have children. She is a lovely character, both inside and out. The name Liliana (De Felice 1986, 233); (Hanks \& Hodges 1990, 206) portrays her as having the beauty, purity and nobility of a lily. Her husband, whom the Inspector does not like very much, the inspector is described as an affectionate husband although rarely present. He represents the typical male of the Fascist era; strong and with a love for hunting. He bears the double-barrelled name Remo Eleuterio (De Felice 1986, 140, 314); (Terzoli 2007, 1230). The first name, Remo, together with the morpheme Bald- 'bold' from the surname Bald-ucci (De Felice 1986, 84), conveys the idea of virility even though he has not helped to produce children. The whole novel is laced with irony, especially regarding men.

There is Lulù, a female Pekinese, which later mysteriously disappears a little before the crime while being taken for a walk by Assunta, one of the characters suspected not of the murder but of being an accomplice. The name Lulù, taken from the world of operetta and often given to pets, sheds light on the dog's main activity, which consists in barking; but not for long, because it soon disappears rather mysteriously. Lulu's disappearance is connected to the death of her owner. In fact when the lady of the house is killed the little dog is already not at home any more. Maybe it was kidnapped so that the Signora could not be warned by its barking. Both names begin with $L$ and the first syllable is repeated: Lili-ana and Lulù connoting ties and shared destinies. Then we have Tina (a frequent hypocorism for Assunta (De Felice 1986, 79); (Rossebastiano \& Papa 2005, 164), known as Assuntina 
by her table companions at a famous lunch, where directly or indirectly later all the suspects are present. (Especially in centuries past in Italy hypocorisms were characteristically used among the serving classes.) However Inspector Ingravallo thinks it is better to call her Assuntona (big Assunta) 'with that chest' and the author graphically describes her prosperous beauty in a 'crescendo' from Tina to Assunta to Assuntina to Assuntona.

Signora Liliana's cousin, who is one of the suspects later released, is officially introduced at the meal as 'Signorino Giuliano' - a noble name (Giuliano: (De Felice $1986,195))$ from ancient Rome. Also his parents are given high-sounding names: Romolo (a name of Latin origin: (De Felice 1986, 320) and Matilde (a Germanic name: (De Felice 1986, 256). Regarding this, one may observe that the writer makes great use of Roman names like Remo (Signora Liliana's husband) and here Romulus. But also the two poor people Enea and Lavinia have names (De Felice 1986, 145, 224) which hark back to the origins of Rome. In these very pompous nominations of individuals who are deep down just modest people one may discern Gadda's irony towards the grandiloquent Fascist era, which is antiphrastically and ironically identified as having the same origins as Rome (Bolla 1976, 89). Note that on the other hand the beautiful and very noble Liliana, the victim, is given a modern simple and pretty name (Pissarello 2010).

Names characterised by dialect (Cavallini 1977; Benedetti 1987; Donnarumma 2006) are inserted into a work which was a great innovation by Gadda; so we have his use of dialect alongside standard Italian and the use of several different registers: upper class, middle class, lower class, according to who is speaking. This is also reflected in the naming. The lower classes have very expressive names and surnames: Bottafavi and Crocchiapani (see above). The upper classes have more classical sounding names like Balducci, Menegazzi and Angeloni. The two very honest and competent detectives do have names and surnames but they are identified by their nicknames, given by ordinary people: one Biondone (big blond) Gaudenzio and the other lo Sgranfia (the talon) Pompeo (Gaudenzio and Pompeo are also of Latin origin: (De Felice 1986, 180, 303)).

\section{[3] IL GIORNO DELLA CIVETTA}

1961 sees the publication of Il giorno della civetta (The Day of the Owl) a novel about the Mafia which brought Leonardo Sciascia a large part of his celebrity. His social commitment and his denunciations of crime in Sicily were to become pertinent traits for a definition of the profile of this writer and intellectual (Traina 1999). This novel is about a carabiniere, Captain Bellodi, originally from Parma (his surname is typical of Modena, near Parma). Bellodi is looking for the perpetrators and planners of two crimes clearly carried out by the Sicilian Mafia. While he utters his surname Bellodi ('listen well' - -odi is a suffix which coincides with a part of the verb udire - 'to hear' - and this has been utilised well by the writer) the 
wise inspector is about to file the deposition for his inquiry but later gets transferred. The wife of one of the two dead people is incriminated on the grounds that she has a lover and could have killed her husband, thus hinting at a crime of passion, while all along it is a crime committed by the Mafia. While all the other Christian names and all the surnames of the novel are typically Sicilian, only this courageous northerner has a non-Sicilian name, suggesting that he is alien to the Sicilian world of connivance, omertà (a conspiracy of silence) and fear. It is difficult for a local person from the island to mount a campaign against the Mafia. The name Bellodi stands in parallel and contrast to the name Dibella with the same morpheme Bell- 'beautiful': this is an ambiguous police informer with double meanings. His full name is Calogero Dibella, know as Zicchineddu (a gamble).

\section{[4] LA DONNA DELLA DOMENICA}

1972 brings La donna della domenica (The Sunday Woman) by Carlo Fruttero and Franco Lucentini, from Piemonte in northern Italy. In this novel all the surnames have a clearly defining function (Arcamone 2007). Unlike in the previous novels here the murderer is unmasked thanks to inspector Santamaria's intelligence and familiarity with Turin's high society. He is, like many Italian policemen, of Sicilian origin, as is his pleasant surname which is very common in Sicily. The inspector is a bachelor. He is naturally elegant, very tactful and chivalrous with a young and beautiful woman from Turin high society who has the lovely double-barrelled name of Anna Carla. For a while she is unjustly suspected. An interest begins to spark between them which is echoed by the inspector's Christian name Francesco, a pan-Italian name (see above, (De Felice 1986,175)) - the name of the patron saint of Italy, worthy to stand beside Santa Maria, which harmonises with Francesca, the name of the beautiful baby girl belonging to Signora Anna Carla. (We noted this previously at the given name of inspector Francesco Ingravallo; intertextuality with Gadda is not excluded).

The policemen have southern or Venetian names such as De Palma, Macaluso, Ruffo and Picco (De Felice 1978, 156, 186, 218). It was from the south of Italy and from the Veneto region that many families arrived to find work in the famous industrial triangle - Turin-Genoa-Milan - after the Second World War. The people from Turin have names frequently found in Piemonte. Among these is Garrone, one of the two people killed. He is a failed, obscene architect, a sponge and a parasite. The name means 'heel' in the Piemontese dialect. He is a friend of a seedy figure called Zavattaro (= ciabattaio: (De Felice 1978, 271)) which means 'slippermaker'. There are two university professors who are each others' enemies. Their names are Bonetto 'the name of an exquisite Turinese sweet', the softer of the two; while the other apparently slightly more sinister is called Marpioli (which means 'slyboots'). In this novel also the dense toponymy, as in the Pasticciaccio, identifies 
the places and actually carries the reader towards a natural conclusion and the consignment of the murderer into the hands of the law.

\section{[5] DONNE INFORMATE SUI FATTI}

In the 2006 novel Donne informate sui fatti (Women Informed of the Facts) by Carlo Fruttero alone, we witness an innovation. First and foremost, the events unwind through the reflections of about ten women. Also the murderer is a woman. A school housekeeper finds the dead body of a young woman. There is a barmaid who has seen the body but not reported it. There is the daughter of the dead woman's husband, her friend, a female carabiniere, a female journalist, a female volunteer, etc.. This novel has an original format like other texts by Fruttero. Its events also take place in a modern setting: here the classic figure of the police inspector is lacking, while it is the attentive female carabiniere who discovers the truth, aided by the reflections of the other women. The dead woman was originally from Rumania - a common origin of many immigrants in Italy today. The motive is classic, the murderer is passionate and predictable - she is the best friend of the family, ex-lover of the widower father. The events in this story take place in Turin and a few surnames are present: Covino (De Felice 1978, 109) - the school housekeeper, Dragonero (De Felice 1978, 116) - the gardener. However a few characters have no names. Others are referred to by their Christian names but their connotations do not identify anyone in particular.

Only one character's name merits comment: it is the name of the lady who is ironically referred to in the novel as 'the best friend of the family'. She first appears as the lover of the father and later as the murderer of the young woman. Her name is Beat-rice (De Felice 1986, 87), 'she who makes people happy' (Italian beato 'blessed', adjective). We may remember it was the name of the woman Dante loved. But her true, terrible nature was anticipated by her schoolfellows, who, changing a single letter and so a single vowel, called her Be-atroce, which means 'atrocious, dreadful, terrible'.

\section{[6] LA MODISTA. UN ROMANZO CON GUARDIA E LADRI}

On the other hand the identifying function of names is extremely clear and emphatic in the last novel to be examined here: La modista. Un romanzo con guardia e ladri (The Milliner. A Novel with a Cop and Robbers) by Andrea Vitali, published in 2008. It is both a detective story and an Italian comedy, for its format is one of irony and laughter. The story is set on Lake Como in Lombardy during the Second World War. It is full of characters with allusive and connotative 'speaking' names and surnames (Milani 2010). Also its toponymy makes a contribution to the construction of the identity of its individuals and especially its main characters. Here there are no murder victims; but there are burglaries, ambiguous characters and 
dead suspects. Everything revolves around a beautiful woman and her various lovers and admirers, beginning with inspector Carmine Accadi (De Felice 1978, 42); (De Felice 1986, 100). He too, like the other commissioners cited here, is of Sicilian origin as the name reveals. He is single and he is vain. Instead of investigating the burglary (introduced at the beginning of the book), he thinks only about wooing the beautiful Anna Montani (De Felice 1978, 173); (De Felice 1986, 67). Here we may primarily observe the author's predilection for proper names which today would be perceived as being heavy and outdated. We have: Adelmo, Aimone (a traditional name from Savoy), Firmato, Eutrice, Gerbera, etc. (De Felice 1986, 42, 49). For surnames indicating regional origin (like the Gaddian Ingravallo and Sciascia's Bellodi) here we have Gravedoni, Fiorinelli, Pani and Bassi - all typical of Lombardy. Then there is the journalist Bentipenso (I think of you well), the arrogant magistrate Scannati (scannare means 'to slit someone's throat': (De Felice 1978, 227)) who has a reputation of being threatening; there is Gargassa (Garg- means 'throat') whose conduct is not, shall we say, gentlemanly. He is Anna Montani's lover and his name is in fact Romeo. But this name is ironic, because it is in contrast not only to the triviality of the surname but also to the low moral status of this individual. The name Eutrice Denti (denti means 'teeth') is interesting. She is the mother of Eugenio (De Felice 1986, 157): as her surname connotes, her judgements are cutting. Then there is the perverted Austera (austere) - here the name is used in an antiphrastic sense. A clear-cut speaking name is given to another one of Anna Montani's lovers Eugenio Pochezza. The first part of his first name (Eu-) rhymes with his mother's name Eutrice. He depends on her morally. His surname (Pochez$z a$ meaning 'smallness') is indicative of his modest personality coupled with his being a rich layabout. He is perhaps responsible for the death of his mother Eutrice to whom he administered too many sleeping drops so that the meeting with his lover would be peaceful and unknown to his stern mother. Furthermore although he loves this beautiful woman who he had decided to marry, he ends up by not marrying her, but instead keeps her on as a lover. In the figure of the main character Anna Montani whose name and surname are without any particular references we cannot exclude the possibility that her name was influenced by the name Anna Magnani (a famous Italian film actress).

In fact there is a lot in this book that reminds us of the cinema and previous detective stories brought to the big and small screens as I have already suggested previously.

\section{[7] CONCLUDING REMARKS}

To sum up I hold that writers - the authors of Italian detective stories - look for an ally in the nominatio to help them define the identity of their characters and the backdrop of their story. In all the novels I have examined in this paper, proper names contain clues as to character and even physical appearance. For example, 
Don Ciccio Ingravallo is 'grave', in the sense of 'reflective', but he is also sturdily built, as suggested by the familiar form Ciccio. Liliana Valdarena is as delicate and as sweet as a lily, but also cloying, like its scent. Assuntona Crocchiapani is a good-looking working-class girl, whose figure and manners are encapsuled in the augmentive suffix -ona and the noisy, bread-crunching surname, Crocchiapani. Giuliano Valdarena combines a name of noble origin (Iulianus < gens Iulia) with an elegant sequence of vowels. In the case of the carabiniere, Captain Bellodi, his Christian name is never used, just as the private life of this faithful servant of the State is never referred to. What does stand out is his integrity, in clear contrast with the ironically named Calogero Dibella, known as Zicchineddu, the police informer. The name of Francesco Santamaria, the canny Sicilian inspector, brings suggestions of virtue and chivalry thanks to the association with Saint Francis of Assisi and, on a higher level still, the Mother of God herself. A change of vowels - from Beatrice to Beat-roce - takes us from the apparently angelic to the underlying diabolic nature of the woman in question. Finally, in the case of the confirmed bachelor Eugenio Pochezza, the character's subjection to his mother is underlined by the first syllable of her name, the diphthong eu-, while his surname conveys the dearth of moral principles that will lead him to murder her - almost by mistake.

\section{REFERENCES}

Amigoni, F. 2002. Spinaci. The Edinburgh Journal of Gadda Studies (=EJGS) 2. www.gadda.ed.ac.uk/Pages/resources/walks/pge/ spinaciamigo.php $(\operatorname{read} 28 / 7 / 2009)$.

Arcamone, M.G. 2007. La donna della domenica. il Nome nel testo 9. 11-16.

Benedetti, C. 1987. Una trappola di parole: lettura del Pasticciaccio. Pisa: Edizioni ETS.

Bolla, E. 1976. Come leggere Quer pasticciaccio brutto de via Merulana di Carlo Emilio Gadda. Milano: Mursia.

Cavallini, G. 1977. Lingua e dialetto in Gadda. Messina/Firenze: D’Anna.

Crovi, L. 2002. Tutti i colori del giallo. Il giallo italiano da De Marchi a Scerbanenco a Camilleri. Venezia: Marsilio.

De Felice, E. 1978. Dizionario dei cognomi italiani. Milano: Mondadori.

De Felice, E. 1986. Dizionario dei nomi italiani. Milano: Mondadori.

Debus, F. 2002. Namen in literarischen Werken: (Er-)findung - Form - Funktion. Stuttgart: Franz Steiner. 
Devoto, G. \& G. Oli. 1990. Il dizionario della lingua italiana. Firenze: Le Monnier (=UTET).

Donnarumma, R. 2006. Gadda modernista. Pisa: Edizioni ETS.

Fruttero, C. 2006. Donne informate sui fatti. Milano: Mondatori.

Fruttero, C. \& F. Lucentini. 1972. La donna della domenica. Milano: Adelphi.

Gadda, C.E. 1957. Quer pasticciaccio brutto de via Merulana. Milano: Garzanti.

Gioanola, E. 2004. Carlo emilio gadda. Milano: Jaca Book.

Hanks, P. \& F. Hodges. 1990. A dictionary of first names. Oxford/New York: Oxford University Press.

Milani, M. 2010. Nomi e personaggi di una nuova commedia all'italiana: La modista di Andrea Vitali. il Nome nel testo 11. 131-150.

Minervini, P. 2008. Appendice al Dizionario dei cognomi pugliesi. Fasano: Schiena.

Pissarello, G. 2010. Un nome floreale nella letteratura inglese modernista: Lily. il Nome nel testo 11. 393-402.

Porcelli, B. 2009. Il giallo italiano negli anni 2006-2008 (all'incirca) e i suoi nomi. Rivista di letteratura italiana 27/2. 69-78.

Porcelli, B. \& L. Terrusi. 2005. L'onomastica letteraria in Italia dal 1980 al 2005. Repertorio bibliografico con abstracts. Pisa: Edizioni ETS.

Reuter, Y. 1997. Le roman policier. Paris: Editions Nathan.

Rossebastiano, A. \& E. Papa. 2005. I nomi di persona in Italia. Dizionario storico ed etimologico. 2 vols. Torino: UTET.

Sciascia, L. 1961. Il giorno della civetta. Milano: Adelphi.

Sciascia, L. 1983. Breve storia del romanzo poliziesco. In Ambroise C. (ed.), Opere 1971-1983, 1179-1196. Milano: Bompiani.

Terzoli, M.A. 2007. Onomastica e calendari nel Pasticciaccio di Carlo Emilio Gadda. In Studi in onore di Pier Vincenzo Mengaldo per i suoi settant'anni (a cura degli allievi padovani). 2 vols., vol. 2, 1225-1248. Galluzzo: Sismel.

Traina, G. 1999. Leonardo Sciascia. Milano: Mondatori.

Vitali, A. 2005. La modista. Milano: Garzanti. 
AUTHOR CONTACT INFORMATION

Maria Giovanna Arcamone

University of Pisa

Department of Linguistics

Via Santa Maria 36

56126 Pisa

Italy

arcamone@ling . unipi.it 